\title{
Gastric Cancer pN2 TNM Finding v7
}

National Cancer Institute

\section{Source}

National Cancer Institute. Gastric Cancer pN2 TNM Finding v7. NCI Thesaurus. Code C89846.

Gastric cancer with metastasis in 3-6 regional lymph nodes. (from AJCC 7th Ed.) 